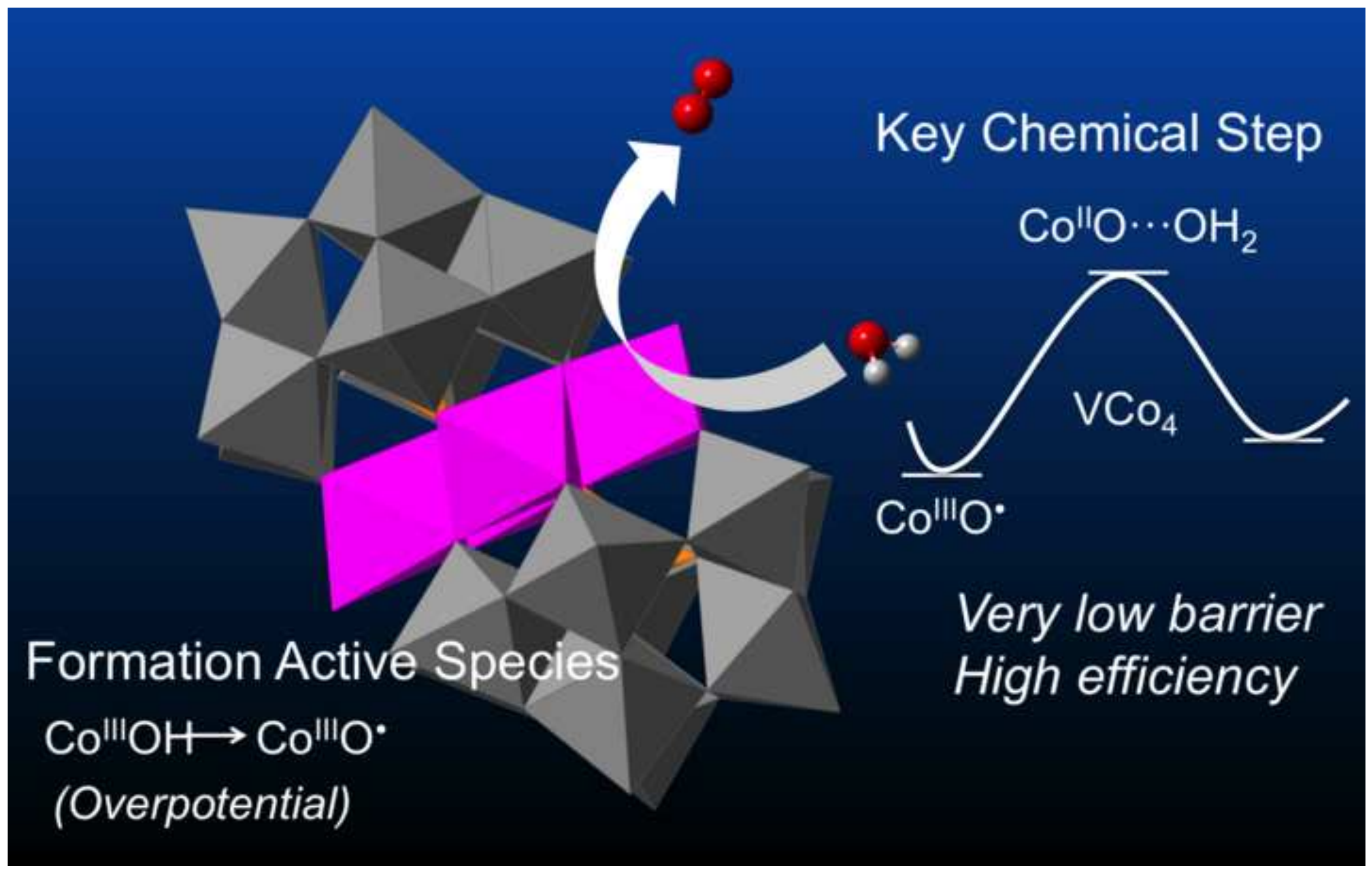




\title{
TetraCobalt-Polyoxometalate Catalysts for Water Oxidation: Key Mechanistic Details
}

\author{
Joaquín Soriano-López, ${ }^{\dagger, \S}$ Djamaladdin G. Musaev, ${ }^{*, \perp}$ Craig Hill, $\perp$ \\ José Ramón Galán-Mascarós, ${ }^{\dagger}$ Jorge J. Carbó, ${ }^{*,}$ Josep M. Poblet ${ }^{*, \S}$
}

\begin{abstract}
A mechanism of water oxidation catalyzed by the carbon-free tetra-Co containing polyoxometalates $\left[\mathrm{Co}_{4}\left(\mathrm{H}_{2} \mathrm{O}\right)_{2}\left(\mathrm{PW}_{9} \mathrm{O}_{34}\right)_{2}\right]^{10-}\left(\mathbf{P C o}_{4}\right)$ and $\left[\mathrm{Co}_{4}\left(\mathrm{H}_{2} \mathrm{O}\right)_{2}\left(\mathrm{VW}_{9} \mathrm{O}_{34}\right)_{2}\right]^{10-}\left(\mathbf{V C o}_{4}\right)$ is elucidated by DFT calculations. Computational analysis for $\mathbf{P C o}_{4}$ suggests that a first PCET step may proceed via a sequential electron-then-proton transfer (ET+PT) pathway and leads to one electron oxidize species $\mathbf{S}_{1}\left(\mathrm{POM}-\mathrm{Co}^{\mathrm{III}}-\mathrm{OH}\right)$. In contrast, the second PCET, which controls the potential required to form POM-Co ${ }^{\mathrm{III}}-\mathrm{O}^{\bullet}$ active species $\mathbf{S}_{2}$ is clearly a concerted process. The overall $\mathbf{S}_{0} \rightarrow \mathbf{S}_{2}$ transformation is estimated to require less than $1.48 \mathrm{~V}$ and $1.62 \mathrm{~V}$ applied potential at $\mathrm{pH}=8$ for $\mathbf{P C o}_{4}$ and $\mathbf{V C o}_{4}$ anions, respectively. At operando conditions, with the presence of a buffer and with an applied potential above the threshold potential the two $\mathrm{H}$-atom removal could take place via concerted pathways. These steps represent rapid pre-equilibria before the rate determining step, which corresponds to the $\mathrm{O}-\mathrm{O}$ bond formation. The key chemical step occurs via nucleophilic attack of an external water molecule to intermediate $\mathbf{S}_{2}$. We assume that this step governs the kinetics of the reaction. Comparison of the calculated energetics and electronic structures of intermediate species in the $\mathbf{P C \mathbf { o } _ { 4 }}$ and $\mathbf{V C \mathbf { o } _ { 4 }}$ catalyzed water oxidation cycle shows that coupling of d orbitals of $\mathrm{V}$ and Co atoms in $\mathbf{V C \mathbf { o } _ { 4 }}$ increases the oxidation potential of the Co-center. The orbital coupling is also responsible for the higher catalytic activity of $\mathbf{V C o}_{4}$ because it increases the electrophilicity of $\mathrm{Co}^{\mathrm{III}}-\mathrm{O}^{\cdot}$ moiety in the key $\mathbf{S}_{\mathbf{2}}$ species.
\end{abstract}

\section{INTRODUCTION}

Natural photosynthesis in higher green plants involves complex reactions that use solar energy to oxidize $\mathrm{H}_{2} \mathrm{O}$ into $\mathrm{O}_{2}$ within the Photosystem II (PSII) and generates reducing equivalents, which are used by Photosystem I (PSI) to reduce $\mathrm{CO}_{2}$ to carbohydrates. The aim of the artificial photosynthesis is the harvesting of the solar energy and its storage in chemical bonds, by means of water splitting obtaining fuels and oxygen.[1, 2$]$ One of the bottlenecks of artificial photosynthesis is the design of a efficient water oxidation catalyst (WOC), which has to be fast, inexpensive, robust, and has to enable the water oxidation close to the thermodynamic potential working in environmentally friendly conditions. [3]

Recently, numerous homogeneous molecular water oxidation catalysts have been reported,[4-19] among which carbon-free polyoxometalate (POM) complexes are promising. [20, 21] These complexes act as WOCs in both homogeneous and heterogeneous conditions, $[22,23]$ and yet, are allinorganic species with high stability towards oxidative degradation. [24, 25]

The first reported $\mathrm{POM}$ showing effective water oxidation activity was the $\left[\mathrm{Ru}_{4} \mathrm{O}_{4}(\mathrm{OH})_{2}\left(\mathrm{H}_{2} \mathrm{O}\right)_{4}(\gamma\right.$ $\left.\left.\mathrm{SiW}_{10} \mathrm{O}_{36}\right)_{2}\right]^{10-}$ complex.[26-31] However, recently POMs with earth-abundant metals showing superior water oxidation activity were foci of chemical and catalytic sciences.

In 2010, Hill and co-workers have reported the first Co-containing polyoxometalate WOC, $\left[\mathrm{Co}_{4}\left(\mathrm{H}_{2} \mathrm{O}\right)_{2}\left(\mathrm{PW}_{9} \mathrm{O}_{34}\right)_{2}\right]^{10^{-}} \quad\left(\mathbf{P C o}_{4}\right) \cdot[32, \quad 33]$ This complex contains a tetracobalt oxide core that is sandwiched by two lacunary $\mathrm{PW}_{9} \mathrm{O}_{34}$ polytungstate cages with phosphorus atoms inside the cage (see Figure 1). 
A higher nuclearity Co-containing $\mathrm{POM}$, the nonanuclear $\left[\mathrm{Co}_{9}\left(\mathrm{H}_{2} \mathrm{O}\right)_{6}(\mathrm{OH})_{3}\left(\mathrm{HPO}_{4}\right)_{2}\left(\mathrm{PW}_{9} \mathrm{O}_{34}\right)_{3}\right]^{16-}$ $\left(\mathrm{PCo}_{9}\right)$ cluster, has also exhibited WOC performance both in homogeneous conditions[34] and in the solid state, when incorporated into a carbon paste modified electrodes. This complex shows high oxygen evolution rates in a wide range of pH.[35] The replacement of $\mathrm{P}^{\mathrm{V}}$ in $\mathbf{P C o}_{4}$ with $\mathrm{V}^{\mathrm{V}}$ leads to $\left[\mathrm{Co}_{4}\left(\mathrm{H}_{2} \mathrm{O}\right)_{2}\left(\mathrm{VW}_{9} \mathrm{O}_{34}\right)_{2}\right]^{10-}\left(\mathbf{V C o}_{4}\right)$, which is about 20 times faster than the phosphorus analog $\mathbf{P C o}_{4}$ using $\left[\mathrm{Ru}(\mathrm{bpy})_{3}\right]^{3+}$ as chemical oxidant under dark conditions at $\mathrm{pH}=9$. Besides their intrinsic interest, Co-containing POMs can be viewed as discrete molecular models of extended heterogeneous cobalt oxide catalyst due to their apparent structural analogy. The much studied Kanan-Nocera heterogeneous cobalt oxide phosphate WOC $\left(\mathrm{CoP}_{\mathrm{i}}\right)_{[36]}$ has some structural features in common with these poly-cobalt POMs.

Atomistic level understanding of mechanisms and governing factors of water oxidation by transition metal catalysts is expected to advance on the design of more efficient, stable, fast and costeffective WOCs. The mechanism of water oxidation catalyzed by Ru-based systems has been subject of extensive studies.[37-51] However, the mechanism and governing factors of the Co-containing catalysts still remain elusive, and computational approaches are expected to play a crucial role in solution of these problems. Recent mechanistic studies on heterogeneous cobalt oxide catalysts have focused on various cluster and periodic model systems of the cobalt phosphate WOC $\left(\mathrm{CoP}_{\mathrm{i}}\right)\left[5^{2-}\right.$ 57], as well as on recently synthesized homogeneous cubane-type WOCs.[58]

In general, these studies have shown that water oxidation by $\mathrm{CoP}_{\mathrm{i}}$ is initiated by successive Proton Coupled Electron Transfer (PCET) events leading to the formation of the active $\mathrm{Co}^{\text {IV }}$-oxo or $\mathrm{Co}^{\mathrm{III}}$-oxyl species, which is involved in the formation of the $\mathrm{O}-\mathrm{O}$ bond. Two different mechanisms for the $\mathrm{O}-\mathrm{O}$ formation have been proposed: i) "water nucleophilic attack" (WNA) mechanism, involving intermolecular nucleophilic attack of external water to the electrophilic $\mathrm{Co}^{\mathrm{IV}}$-oxo or $\mathrm{Co}^{\mathrm{III}}$-oxyl species,[53] and ii) "direct $\mathrm{O}-\mathrm{O}$ coupling" mechanism proceeding via intramolecular direct coupling of two $\mathrm{Co}^{\mathrm{IV}}$-oxo sites.[52] These initial discrepancies were later attributed to the structural differences in the models used.[59]
Here, we elucidate mechanism of water oxidation by the sandwich species $\mathbf{P C \mathbf { o } _ { 4 }}$ and $\mathbf{V C o _ { 4 }}$, which have been extensively studied experimentally. Because of bulkiness and structural stability of these $\mathrm{Co}_{4}-\mathrm{POM}$ anions[32-34] one can eliminate the direct intermolecular $\mathrm{O}-\mathrm{O}$ bond formation mechanism. Therefore, in the present paper, we only investigate in detail by computational means the key steps leading to the formation of the active $\mathrm{Co}^{\mathrm{IV}}$-oxo or $\mathrm{Co}^{\mathrm{III}}$-oxyl species, and WNA to $\mathrm{O}_{2}$ bond formation mechanism of the water oxidation by the tetra-Co-containing POM catalysts.

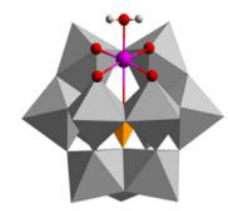

$\mathrm{PCo}_{1}$

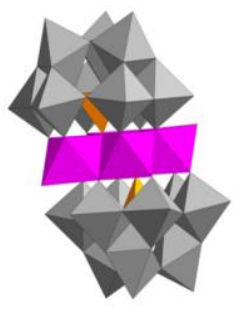

$\mathrm{PCO}_{4}$

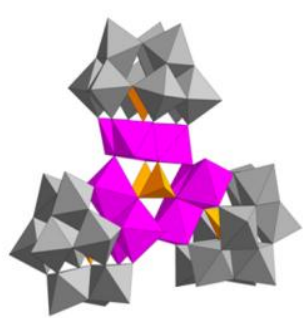

$\mathrm{PCO}_{9}$
Figure 1. Polyhedral representation of the $\left[\mathrm{Co}\left(\mathrm{H}_{2} \mathrm{O}\right) \mathrm{PW}_{11} \mathrm{O}_{39}\right]^{5^{-}}\left(\mathrm{PCo}_{1}\right), \quad\left[\mathrm{Co}_{4}\left(\mathrm{H}_{2} \mathrm{O}\right)_{2}\left(\mathrm{PW}_{9} \mathrm{O}_{34}\right)_{2}\right]^{10-}\left(\mathrm{PCo}_{4}\right)$ and $\quad\left[\mathrm{Co}_{9}\left(\mathrm{H}_{2} \mathrm{O}\right)_{6}(\mathrm{OH})_{3}\left(\mathrm{HPO}_{4}\right)_{2}\left(\mathrm{PW}_{9} \mathrm{O}_{34}\right)_{3}\right]^{16-} \quad\left(\mathrm{PCo}_{9}\right)$ polytungstate anions.

\section{RESULTS AND DISCUSSION}

1. Electronic and Structural Properties of the $\mathrm{PCo}_{4}$ and $\mathrm{VCo}_{4}$ Catalysts. Previous experimental studies have shown[32, 33,6o] that at the resting stages of $\left[\mathrm{Co}_{4}\left(\mathrm{H}_{2} \mathrm{O}\right)_{2}\left(\mathrm{PW}_{9} \mathrm{O}_{34}\right)_{2}\right]^{10-} \quad\left(\mathbf{P C o}_{4}\right)$ and $\left[\mathrm{Co}_{4}\left(\mathrm{H}_{2} \mathrm{O}\right)_{2}\left(\mathrm{VW}_{9} \mathrm{O}_{34}\right)_{2}\right]^{10-}\left(\mathbf{V C o}_{4}\right)$ anions all four $\mathrm{Co}$ atoms are in their $2+$ oxidation states with a formal high-spin $d^{7}$ electron configuration and three unpaired electrons. From these three unpaired electrons two occupy an $e_{g}$-like and one a $t_{2 g}$-like orbitals. In the presented computational (DFT) work, we do not analyze the magnetic coupling among the four $\mathrm{Co}\left(\mathrm{II}, d^{7}\right)$ centers. Thus, we discuss only the high-spin electronic state of the $S_{o}$ species with twelve (three per Co-center) unpaired electrons, in which, for simplicity of our analysis, we fixed $\mathrm{C}_{2 \mathrm{~h}}$ symmetry in both $\mathbf{P C o}_{4}$ and $\mathbf{V C o}_{4}$. Furthermore, in this ground state $\left(\mathbf{S}_{\mathbf{o}}\right)$ of $\mathbf{P C o}_{4}$ and $\mathrm{VCo}_{4}$, the water ligand is linked to the external $\mathrm{Co}^{\mathrm{II}}$ centers with a relatively long $\mathrm{Co}-\mathrm{OH}_{2}$ bond length (2.24 $\AA$ ), and adopted an orientation to accentuate the interactions between the hydrogen atoms and the terminal oxo sites of the POM (with $\mathrm{O}$ $\mathrm{H} \cdots \mathrm{O}=\mathrm{W}$ distance of $\sim 2.01 \AA$, see Figure 2 ). 


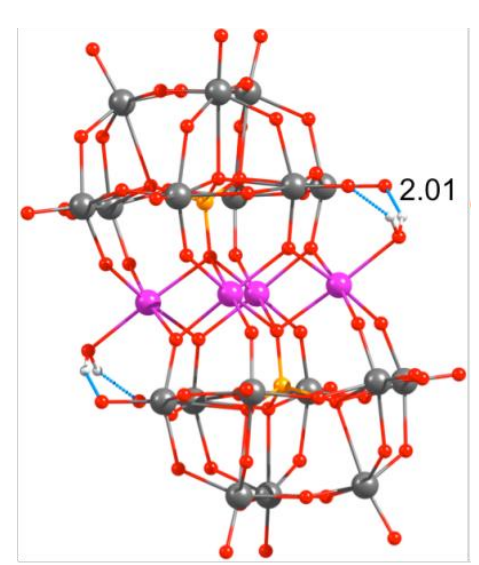

Figure 2. Ball and stick representation for $\mathbf{P C o}_{4}$.

\section{Water oxidation by the $\mathrm{PCo}_{4}$ anion.}

A. Initial steps. Water oxidation is usually catalyzed by using either photo-induced (utilizing organic compounds as electron sinks) or electrochemical (applying a potential to oxidize water) approaches. Below, we focus on the issues related to the electrochemical water oxidation. In the studied process, the oxidation steps of the reactive center are controlled by the applied potential, while the chemical steps of the reaction depend on $\mathrm{O}-\mathrm{H}$ bond cleavage and $\mathrm{O}-\mathrm{O}$ bond formation energies, and dictate the kinetics of the reaction. In other words, in order to initiate the studied water oxidation it is necessary to apply a threshold potential, while the following bond formation/cleavage steps of the reaction do not depend on this applied potential. Keeping in mind these two control factors, along this article we present our results in $\mathrm{V}$ or $\mathrm{kcal} \cdot \mathrm{mol}^{-1}$ (or $\mathrm{eV}$ ) depending if we are referring to the electrochemically or kinetically controlled steps, respectively.

Existing experiments show that most of the catalytic processes utilizing cobalt-containing POMs occur in neutral or basic media (often at $\mathrm{pH}=8$ ).[22-25] Therefore, we focus the discussion of our results considering that the $\mathrm{Co}_{4}$-catalyzed water oxidation occurs at $\mathrm{pH}=8$. Here, we estimate the effect of $\mathrm{pH}$ on a single $\mathbf{S}_{\mathrm{i}} \rightarrow \mathbf{S}_{\mathrm{j}}$ transformation by using standard Nernst eq. 2 , in which we have assumed that $\mathbf{S}_{\mathbf{i}}$ and $\mathbf{S}_{\mathbf{j}}$ species have identical concentrations.

Taking as a starting point the mechanism proposed for single-site cobalt[61-63] and ruthenium[37-44] catalysts, we first analyze the solution speciation of the $\mathbf{S}_{\mathbf{o}}$ species at $\mathrm{pH}=8$. Casey and co-workers[64] studied the rates of water exchange of $\mathbf{P C o}_{4}$ by means of spectroscopic and potentiometric techniques, concluding that the $\mathrm{pK}_{\mathrm{a}}$ for the first deprotonation of the water ligand $\left[\mathbf{S}_{\mathbf{o}}\left(\mathrm{Co}^{\mathrm{II}}-\mathrm{OH}_{2}\right) \rightarrow \mathbf{S}_{\mathbf{o}}{ }^{\prime}\left(\mathrm{Co}^{\mathrm{II}}-\mathrm{OH}\right)\right]$ would be close to 8 .
Shortly after, Ivanović-Burmazović et al.[65] also studied the water exchange reactivity and stability of $\mathrm{PCo}_{4}$ in the 6 to $10 \mathrm{pH}$ range, which is the catalytically relevant $\mathrm{pH}$ region, employing ${ }^{17} \mathrm{O}$ NMR spectroscopy and ultrahigh-resolution electrospray ionization mass spectrometry. In that work, it was found no evidence of Co-hydroxo or $\mathrm{Co}-$ oxo species formation in the studied $\mathrm{pH}$ range ( $\mathrm{pH}=6-10)$. Hence, authors concluded that the $\mathrm{pK}_{\mathrm{a}}$ for the first deprotonation of $\mathbf{P C o}_{4}$ should be higher than 10. Note that the POM is unstable above $\mathrm{pH}=10$. .25] Despite experimental evidences, we decided to compute the deprotonation of $S_{\mathbf{o}}$ species in order to confirm that the $\mathrm{pK}_{\mathrm{a}}$ value could be higher than 10 , and consequently, that the true nature of the catalyst corresponds to the $\mathrm{Co}$ (II)aqua species $\mathbf{S}_{\mathbf{o}}$. For the $\left[\mathbf{S}_{\mathbf{o}}\left(\mathrm{Co}^{\mathrm{II}}-\mathrm{OH}_{2}\right) \rightarrow \mathbf{S}_{\mathbf{o}}{ }^{\prime}\left(\mathrm{Co}^{\mathrm{II}}-\right.\right.$ $\mathrm{OH})$ ] step we have estimated a $\mathrm{pK}_{\mathrm{a}}$ value of 19.7 and an endergonic free energy of $+16.1 \mathrm{kcal} \cdot \mathrm{mol}^{-1}$ at $\mathrm{pH}=8$ (Figure 4). Deviations of computed $\mathrm{pK}_{\mathrm{a}}$ values with respect to experimental ones can be significant as it has already been pointed out. Hence discrepancies between experimental and computed pKa of 5 units are not unusual,[39] where $1 \mathrm{pK}_{\mathrm{a}}$ unit represents $60 \mathrm{meV}, 1.38 \mathrm{kcal} \cdot \mathrm{mol}^{-1}$. Reported experimental data and our present calculations strongly suggest that the $\mathrm{pK}_{\mathrm{a}}$ for the first proton removal step should be higher than 10 . Thus, at $\mathrm{pH}=8$, where catalytic experiments are performed, the predominant species existing in solution is $\mathbf{S}_{\mathbf{o}}\left(\mathrm{Co}^{\mathrm{II}}-\mathrm{OH}_{2}\right)$, whereas the concentration of $\mathbf{S}_{\mathbf{o}}{ }^{\prime}\left(\mathrm{Co}^{\mathrm{II}}-\mathrm{OH}\right)$ species should be negligible.

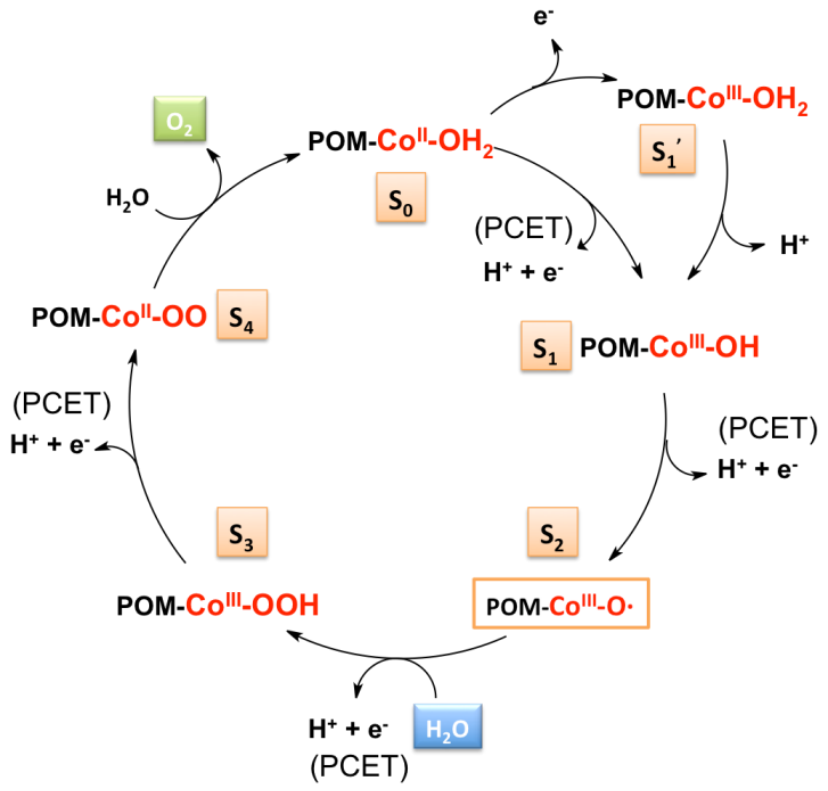

Figure 3. Schematic presentation of the water oxidation single-site catalyst mechanism using cobalt-containing polyoxometalates. 
Thus, we analyze each step of the $\mathbf{P C \mathbf { o } _ { 4 }}$-catalyzed water oxidation cycle at $\mathrm{pH}=8$ starting from the $\mathbf{S}_{\mathbf{0}}\left(\mathrm{CO}^{\mathrm{II}}-\mathrm{OH}_{2}\right)$ species (see Figure 3$)$. According to this mechanism, the first step of the overall process is the $\mathrm{H}$-atom removal from the coordinated water molecule of the resting $\mathrm{Co}^{\mathrm{II}}-\mathrm{OH}_{2}\left(\mathbf{S}_{\mathbf{o}}\right)$ state of the system. This step leads to the $\mathrm{Co}^{\mathrm{III}}-\mathrm{OH}$ species $\left(\mathbf{S}_{\mathbf{1}}\right)$ with one-electron oxidized Co-center (i.e. from $\mathrm{Co}^{\mathrm{II}}$ to $\mathrm{Co}^{\mathrm{III}}$ ) and deprotonated water (i.e. $\mathrm{OH}$ ) ligand. In the next step, the $\mathbf{S}_{1}$ species transforms to the Co ${ }^{\text {III }}$-oxyl species $\left(\mathbf{S}_{\mathbf{2}}\right)$ with one electron oxidized and deprotonated oxyl ligand. Both these steps of the reaction, in general, could occur via either proton-coupled electron transfer (PCET), sequential proton-then-electron transfer (PT+ET) or sequential electron-then-proton transfer $(\mathrm{ET}+\mathrm{PT})$ pathways; hence, we analyze the three of them for each step. The computed free energies are shown in Figure 4 . The vertical steps in the square diagram represent one-electron oxidation reactions, the free energies of which are expressed as standard reduction potentials. Horizontal steps represent acid-base equilibria, the free energies of which may have associated a $\mathrm{pK}_{\mathrm{a}} \cdot[18]$ Finally, diagonal steps represent concerted PCET steps. Hence, the first $\mathrm{H}$-atom removal from the coordinated water molecule, i.e. the $\mathbf{S}_{\mathbf{o}} \rightarrow \mathbf{S}_{\mathbf{1}}$ transition, via the PCET pathway requires $1.51 \mathrm{~V}$ potential $v s$ to NHE. As already mentioned, the PT+ET pathway is unlikely in this step, since deprotonation of the water ligand in the $\boldsymbol{S}_{\mathrm{o}}$ species is thermodynamically unfavorable and it would need strong basic conditions $(\mathrm{pH}>10)$ where $\mathbf{P C o}_{4}$ is unstable. The same step of the reaction proceeding via the sequential $\mathrm{ET}+\mathrm{PT}$ requires lower applied potential $\left(1.27 \mathrm{~V}\right.$ for $\left.\mathbf{S}_{\mathbf{0}} \rightarrow \mathbf{S}_{\mathbf{1}}{ }^{\prime}\right)$ than the concerted PCET $(1.51 \mathrm{~V})$. Nevertheless, the free energy for the subsequent deprotonation $\left(\mathbf{S}_{\mathbf{1}}{ }^{\prime} \rightarrow \mathbf{S}_{\mathbf{1}}\right)$ step is slightly endergonic $+5.5 \mathrm{kcal} \cdot \mathrm{mol}^{-1}(+0.24$ $\mathrm{eV}$ ), and consequently, the ET+PT process requires additional chemical thermal energy in order for the reaction to proceed, slowing down the overall kinetics of the reaction. It is worthy to point out that in the present model bulk water is considered the proton acceptor in the PT events (as well as in the PCET events). This assumption implies that the computed free energies might be viewed as upper limit energies, since actually buffer (phosphate, borate, etc.) may act as the proton acceptor during experimental conditions. In other words, whenever the proton acceptor is a stronger base than bulk water the free energies required to proceed through the deprotonation step will be lower than the computed ones. Therefore, at the reaction conditions where always a buffer is used and the potential is somewhat greater than the minimum required, concerted and sequential paths are competitive.

Once the reaction reaches the $\mathbf{S}_{\mathbf{1}}\left(\mathrm{Co}^{\mathrm{III}}-\mathrm{OH}\right)$ state, the second oxidation process (i.e. $\mathbf{S}_{\mathbf{1}} \rightarrow \mathbf{S}_{2}$ ) proceeds. Following the same procedure, we computed again PCET $\quad\left[\mathbf{S}_{\mathbf{1}}\left(\mathrm{Co}^{\mathrm{III}}-\mathrm{OH}\right) \rightarrow \mathbf{S}_{\mathbf{2}}\left(\mathrm{Co}{ }^{\mathrm{III}}-\mathrm{O}^{*}\right)\right], \quad \mathrm{PT}+\mathrm{ET}$ $\left[\mathbf{S}_{\mathbf{1}}\left(\mathrm{Co}^{\mathrm{III}}-\mathrm{OH}\right) \rightarrow \mathbf{S}_{1}{ }^{\prime \prime}\left(\mathrm{Co}^{\mathrm{III}}-\mathrm{O}\right) \rightarrow \mathbf{S}_{2}\left(\mathrm{Co}{ }^{\mathrm{III}}-\mathrm{O}^{*}\right)\right]$ and $\mathrm{ET}+\mathrm{PT} \quad\left[\mathbf{S}_{1}\left(\mathrm{Co}^{\mathrm{III}}-\mathrm{OH}\right) \rightarrow \mathbf{S}_{2}{ }^{\prime}\left(\mathrm{Co}^{\mathrm{III}}-\mathrm{OH}^{*}\right) \rightarrow \mathbf{S}_{\mathbf{2}}\left(\mathrm{Co}^{\mathrm{III}}-\right.\right.$ $\left.\mathrm{O}^{\circ}\right)$ ] pathways. We found that the $\mathrm{H}$-atom removal from the OH-ligand via the concerted PCET pathway requires an applied potential of $1.48 \mathrm{~V}$. Considering the sequential proton-then-electron transfer pathway (PT+ET), deprotonation of $\mathbf{S}_{\mathbf{1}}\left(\mathrm{Co}^{\mathrm{III}}-\mathrm{OH}\right)$ species requires an energy as high as $+45.8 \mathrm{kcal} \cdot \mathrm{mol}^{-1}(1.99 \mathrm{eV})$. Finally, the sequential electron-then-proton transfer needs an applied potential of $2.59 \mathrm{~V}$ for the ET event. Thus, the two sequential pathways require rather high energies to be initiated, and we can conclude that the second $\mathrm{H}$-atom removal occurs preferably via a concerted PCET event, where the electron and the proton are transferred in one step from the $\mathrm{OH}$-ligand $\left[\mathbf{S}_{\mathbf{1}}\left(\mathrm{Co}^{\mathrm{III}}-\mathrm{OH}\right) \rightarrow \mathbf{S}_{\mathbf{2}}\left(\mathrm{Co}^{\mathrm{III}}-\mathrm{O}^{*}\right)\right]$, with an applied potential of $1.48 \mathrm{~V}$.

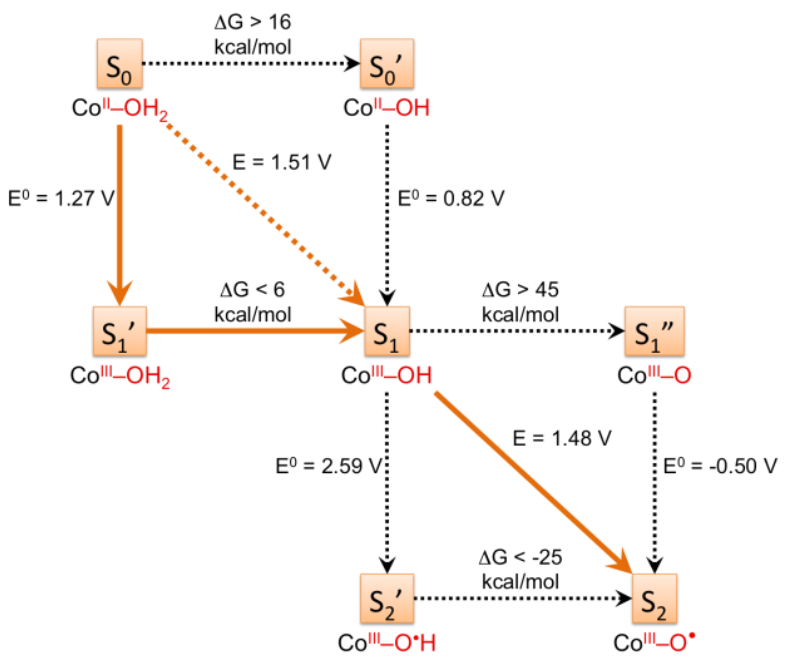

Figure 4. Schematic presentation of the PCET, PT+ET, and $\mathrm{ET}+\mathrm{PT}$ events for $\mathrm{PCo}_{4} \mathrm{WOC}$ at $\mathrm{pH}=8$. Potentials are given in $\mathrm{V}$, whereas values associated to deprotonation steps are given in $\mathrm{kcal} / \mathrm{mol}$. The orange dashed line in the first concerted PCET indicates that the process may become competitive with the sequential ET+PT at $\mathrm{E}_{\mathrm{app}}>1.51 \mathrm{~V}$.

In electrochemical catalysis the potentials are not additives as those are in the chemical catalysis. Therefore, one may conclude that in the electrochemical conditions the formation of the active species $\mathbf{S}_{2}\left(\mathrm{Co}^{\mathrm{III}}-\mathrm{O}^{*}\right)$ will require an applied potential of about $1.5 \mathrm{~V}$ at $\mathrm{pH}=8$. At this potential the concerted PCET of the first $\mathrm{H}$-atom removal $\left(\mathbf{S}_{\mathbf{o}}\right.$ $\rightarrow \mathbf{S}_{\mathbf{1}}$ ) is feasible and we cannot discard that it competes with the sequential $\mathrm{ET}+\mathrm{PT}$ occurring at 
lower potential. These findings are consistent with the previous electrochemical analysis of $\mathbf{P C o}_{4}$. Indeed, previous cyclic voltammetry experiments shown an onset potential of $1.46 \mathrm{~V}$ vs NHE at $\mathrm{pH}=7.8$ for water oxidation using $\mathbf{P C o}_{4}$ as a catalyst.[66]

Despite the complexity presented above, we still can draw the following conclusions from the presented computational findings: 1 ) removal of the first electron (i.e. oxidation of $\mathrm{Co}^{\mathrm{II}}$ to $\mathrm{Co}^{\mathrm{III}}\left(\mathbf{S}_{\mathbf{0}} \rightarrow \mathbf{S}_{\mathbf{1}}{ }^{\prime}\right)$ ) is less energetically demanding than the removal of the second electron (i.e. $\left(\mathbf{S}_{\mathbf{1}} \rightarrow \mathbf{S}_{\mathbf{2}}{ }^{\prime}\right) ; 2$ ) the first oxidation step does not necessarily occur coupled to a proton transfer, while the second oxidation is a concerted PCET event; and 3) the potential required for the overall two-electron redox reaction is determined by the second oxidation step, that is the formation of the active species $\left(\mathbf{S}_{\mathbf{2}}\right)$.

Close examination of geometry parameters of various intermediate oxidation states of $\mathbf{P C o}_{4}$ shows that the change of external $\mathrm{Co}-\mathrm{O}$ bond distance (it is established that in the sandwich POMs the external $\mathrm{TM}-\mathrm{OH}_{2}$ sites are reactive sites[67]) along the water oxidation cycle is consistent with the nature of the oxidation events. Indeed, oxidation of the cobalt center [i.e. $\mathbf{S}_{\mathbf{o}}\left(\mathrm{Co}^{\mathrm{II}}-\right.$ $\left.\left.\mathrm{OH}_{2}\right) \rightarrow \mathbf{S}_{1}{ }^{\prime}\left(\mathrm{Co}^{\mathrm{III}}-\mathrm{OH}_{2}\right)\right]$ shortens the $\mathrm{Co}-\mathrm{OH}_{2}$ bond distance from $2.24 \AA$ to $1.96 \AA$. The following loss of the first [i.e. $\left.\mathbf{S}_{\mathbf{1}}{ }^{\prime}\left(\mathrm{Co}^{\mathrm{III}}-\mathrm{OH}_{2}\right) \rightarrow \mathbf{S}_{\mathbf{1}}\left(\mathrm{Co}^{\mathrm{III}}-\mathrm{OH}\right)\right]$ and the second $\left[\right.$ i.e. $\left.\mathbf{S}_{\mathbf{1}}\left(\mathrm{Co}^{\mathrm{III}}-\mathrm{OH}\right) \rightarrow \mathbf{S}_{\mathbf{2}}\left(\mathrm{Co}^{\mathrm{III}}-\mathrm{O}^{*}\right)\right]$ proton further reduces the calculated $\mathrm{Co}-\mathrm{O}$ bond distance to $1.82 \AA$ and $1.76 \AA$, respectively (see Table 2).

Aforementioned geometry changes are also consistent with the nature of the frontiers orbitals

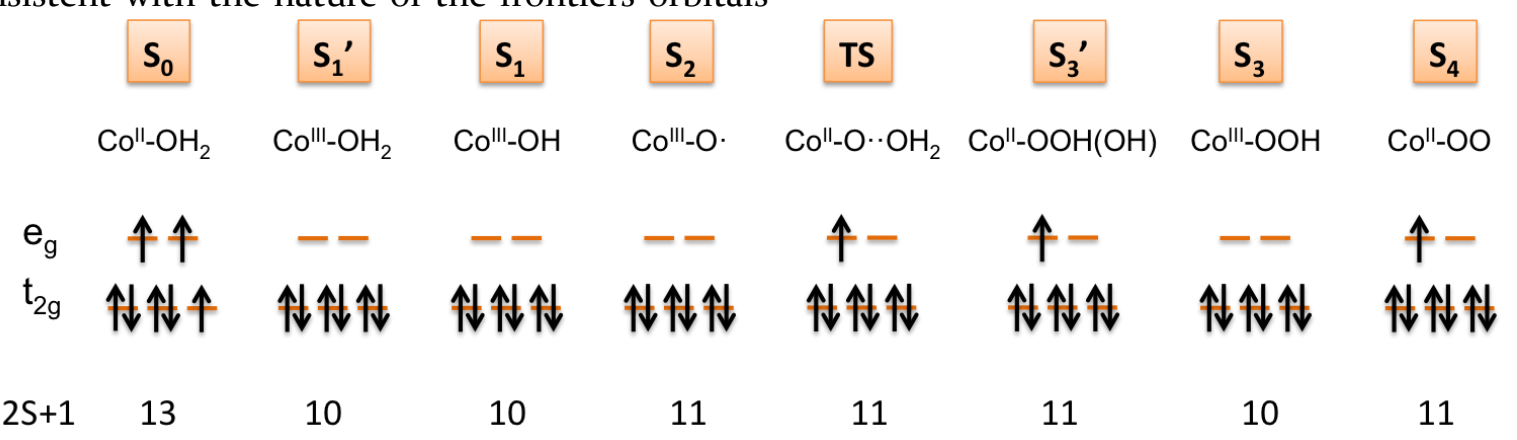

Figure 6. Unpaired spin distribution in the active Co sites of different species involved in the $\mathbf{P C \mathbf { O } _ { 4 }}$ catalyzed water oxidation mechanism.

Table 1. Computed Values for Each Step of the $\mathrm{PCo}_{4}$ - and $\mathrm{VCo}_{4}$-catalyzed Water Oxidation Cycles at $\mathrm{pH}=8$.

\begin{tabular}{|c|c|c|c|c|c|c|c|}
\hline POM & $\begin{array}{c}S_{\mathbf{o}} \rightarrow S_{1}{ }^{, a)} \\
(V)\end{array}$ & $\begin{array}{c}\mathbf{S}_{\mathbf{1}}^{\prime} \rightarrow \mathbf{S}_{\mathbf{1}}^{\mathbf{b}} \\
(\mathrm{eV})\end{array}$ & $S_{1} \rightarrow S_{2}{ }^{a)}(V)$ & $\begin{array}{c}\left.\mathbf{S}_{\mathbf{2}} \rightarrow \mathrm{TS}^{\mathrm{c}}\right) \\
(\mathrm{eV})\end{array}$ & $\begin{array}{c}\left.\mathbf{S}_{2} \rightarrow \mathbf{S}_{3}{ }^{c}\right) \\
(\mathrm{eV})\end{array}$ & $\begin{array}{c}\mathbf{S}_{3}{ }^{\prime} \rightarrow \mathbf{S}_{3}{ }^{\mathbf{a})} \\
(\mathrm{V})\end{array}$ & $\begin{array}{c}\mathrm{S}_{3} \rightarrow \mathrm{S}_{4} \mathbf{a}^{\mathrm{a}} \\
(\mathrm{V})\end{array}$ \\
\hline $\mathrm{PCo}_{4}{ }^{\mathrm{d})}$ & +1.27 & +0.24 & +1.48 & +0.99 & +0.22 & +0.26 & +0.05 \\
\hline $\mathrm{VCo}_{4}{ }^{\mathrm{d})}$ & +1.58 & +0.32 & +1.62 & +0.73 & -0.11 & +0.42 & +0.07 \\
\hline
\end{tabular}

a) For the electrochemical steps the potentials are given in V versus NHE; b) Values corresponding to the deprotonation step $(\mathrm{eV})$; c) Energy values for the activation barrier of the transition state are given in $\mathrm{eV}$. d) Values in bold represent the threshold potentials and energy barriers to overcome for $\mathbf{P C o}_{4}$ and $\mathbf{V C o}_{4}$ at $\mathrm{pH}=8$. of the intermediate species. Indeed, as seen in Figure 5 , the contribution of ligand $\mathrm{p}(\mathrm{O})$ orbital to the $\mathrm{HOMO}$ is significant in $\mathbf{S}_{\mathbf{1}}$ species and, consequently, the next oxidation event is expected to be hydrogen removal from $\mathrm{OH}$-fragment that leads to the $\mathrm{Co}^{\mathrm{III}}$-oxyl species $\mathrm{S}_{2}$ (POM-Co ${ }^{\mathrm{III}}-\mathrm{O}^{*}$ ). Consistently, in $\mathbf{S}_{2}$ species the calculated spin population of oxyl-center is $1.00|\mathrm{e}|$ (see Figures 5 and 6). One should mention that the oxidation of $\mathrm{Co}^{\mathrm{III}}-\mathrm{OH}$ leads to the $\mathrm{Co}^{\mathrm{III}}-\mathrm{O}^{\bullet}$ species rather than the $\mathrm{Co}^{\mathrm{IV}}-\mathrm{O}$ unit. A similar result was previously reported for cobalt oxide cubane systems[52] and single-site Co-corrole catalysts.[61-63] More recently, DFT and CASSCF studies of the Co derivatives of POMs also revealed that the formation of a $\mathrm{Co}^{\mathrm{IV}}$ species is energetically unfavorable.[68] Similarly, for Ru-containing POMs, it was suggested that the $\mathrm{Ru}^{\mathrm{VI}}$-oxo groups are formally closer to being $\mathrm{Ru}^{\mathrm{V}}$-oxyl radicals. [45]
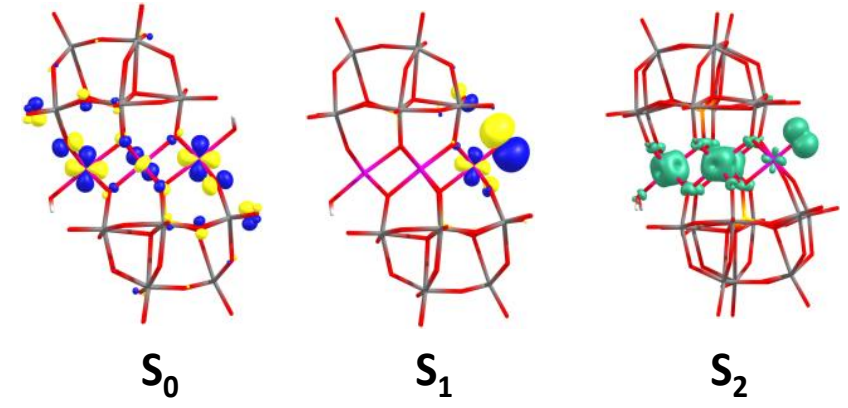

Figure 5. The HOMOs and the spin densities of several species of the $\mathbf{P C o}_{4}$-catalyzed water oxidation cycle. 
Table 2. The Calculated Co-O Bond Distances (in $\AA$ ) and Unpaired Mulliken Spin Densities (in $|\mathbf{e}|$ ) of the Co and "active" O-centers for the Different Intermediate Species $\left(S_{\mathrm{i}}\right)$ of the $\mathrm{PCo}_{4}$-and $\mathrm{VCo}_{4}$-catalyzed Water Oxidation Cycles. ${ }^{\text {a) }}$

\begin{tabular}{|c|c|c|c|c|c|c|c|c|c|}
\hline & POM & $\begin{array}{c}\mathrm{S}_{\mathrm{o}} \\
\mathrm{Co}^{\mathrm{II}}-\mathrm{OH}_{2}\end{array}$ & $\begin{array}{c}\mathrm{S}_{1}^{\prime} \\
\mathrm{Co}^{\mathrm{III}}-\mathrm{OH}_{2}\end{array}$ & $\begin{array}{c}\mathrm{S}_{1} \\
\mathrm{Co}^{\mathrm{III}}-\mathrm{OH}\end{array}$ & $\begin{array}{c}\mathrm{S}_{2} \\
\mathrm{Co}^{\mathrm{III}}-\mathrm{O} .\end{array}$ & $\begin{array}{c}\text { TS } \\
\mathrm{Co}^{\mathrm{II}}-\mathrm{O}+\mathrm{H}_{2} \mathrm{O}\end{array}$ & $\begin{array}{c}\mathrm{S}_{3}{ }^{\prime} \\
\mathrm{Co}^{\mathrm{II}}-\mathrm{OOH}(\mathrm{OH})\end{array}$ & $\begin{array}{c}\mathrm{S}_{3} \\
\mathrm{Co}^{\mathrm{III}}-\mathrm{OOH}\end{array}$ & $\begin{array}{c}\mathrm{S}_{4} \\
\mathrm{Co}^{\mathrm{II}}-\mathrm{OO}\end{array}$ \\
\hline \multirow[t]{2}{*}{$\mathrm{d}\left(\mathrm{Co}_{\mathrm{o}} \mathrm{O}_{\mathrm{t}}\right)$} & $\mathrm{PCo}_{4}$ & 2.240 & 1.956 & 1.820 & 1.760 & 1.730 & 1.876 & 1.832 & 2.060 \\
\hline & $\mathrm{VCo}_{4}$ & 2.220 & 1.968 & 1.821 & 1.761 & 1.734 & 1.867 & 1.833 & 2.013 \\
\hline \multirow[t]{2}{*}{$\mathrm{d}\left(\mathrm{Co}-\mathrm{O}_{\mathrm{c}}\right)$} & $\mathrm{PCo}_{4}$ & 2.240 & 1.969 & 2.100 & 2.100 & 2.070 & 2.097 & 2.106 & 2.164 \\
\hline & $\mathrm{VCo}_{4}$ & 2.150 & 1.938 & 2.064 & 2.062 & 2.018 & 2.066 & 2.062 & 2.117 \\
\hline \multirow[t]{2}{*}{$\rho($ Co $)$} & $\mathrm{PCo}_{4}$ & 2.73 & 0.00 & 0.00 & -0.04 & 1.15 & 1.01 & 0.01 & 0.79 \\
\hline & $\mathrm{VCo}_{4}$ & 2.78 & 0.00 & -0.01 & -0.06 & 1.35 & 1.03 & -0.01 & 0.71 \\
\hline \multirow[t]{2}{*}{$\rho(\mathrm{O})$} & $\mathrm{PCo}_{4}$ & 0.03 & 0.00 & -0.01 & 1.00 & $-0.14(-0.10)$ & $-0.06(-0.01)$ & $-0.01(0.00)$ & $0.09(0.15)$ \\
\hline & $\mathrm{VCo}_{4}$ & 0.03 & 0.00 & 0.01 & 1.01 & $-0.26(-0.17)$ & $-0.08(-0.01)$ & $0.00(0.00)$ & $0.110 .21)$ \\
\hline
\end{tabular}

a) Values in parentheses are for the second oxygen atom after the $\mathrm{O}-\mathrm{O}$ bond formation.

B. The O-O bond formation: Nucleophilic attack of water to the Co ${ }^{\text {III }}$-oxyl $\left(S_{2}\right)$ species. Once the active cobalt-oxyl species $\left(\mathbf{S}_{\mathbf{2}}\right)$ is formed, next step of the water oxidation by $\mathrm{Co}_{4}-\mathrm{POM}$ catalyst is the $\mathrm{O}-\mathrm{O}$ bond formation, which, as we mentioned above, is expected to occur via the WNA mechanism. This process, which is initiated by the nucleophilic attack of an "external" water molecule to the $\mathrm{Co}^{\text {III }}$-oxyl intermediate $\mathbf{S}_{\mathbf{2}}$, will be followed by two more PCET events, and will release molecular $\mathrm{O}_{2}$. Once again, we rule out the intramolecular formation of $\mathrm{O}-\mathrm{O}$ bond from two Co-oxyl groups in the same POM because of large distance between these two oxo atoms (>9.6 $)$.

As seen in Figure 6, nucleophilic attack of water to intermediate $\mathbf{S}_{\mathbf{2}}\left(\mathrm{Co}^{\mathrm{III}}-\mathrm{O}^{\circ}\right)$ yields $\left[\mathrm{Co}^{\mathrm{II}}(\mathbf{O O H}) \mathrm{Co}_{3}{ }^{\mathrm{II}}\right.$ $\left.\left(\mathrm{H}_{2} \mathrm{O}\right)\left(\mathrm{PW}_{9} \mathrm{O}_{34}\right)_{2} \mathbf{H}\right]^{10-}\left(\mathbf{S}_{3}^{\prime}\right)$ species, where one of the protons of coordinated (external) water is transferred to a basic oxygen atom of the POM in a concerted manner, as shown in Figure 7 . Since oxygens of the $\mathrm{Co}-\mathrm{O}-\mathrm{W}$ bridges are the most basic ones, they are the most likely to be protonated.[6972] The free energy barrier for the water $\mathrm{HO}-\mathrm{H}$ bond activation is calculated to be $0.99 \mathrm{eV}$ at the transition state TS (see Table 1 and Figure 8). We note that the LUMO+1 of the active $\mathbf{S}_{2}\left(\mathrm{Co}^{\text {IIII }}-\mathrm{O}^{*}\right)$ species, has a $\mathrm{Co}-\mathrm{O} \pi^{*}$-antibonding character (Figure 7) and is significantly polarized toward the oxyl ligand; this clearly favors the nucleophilic attack of a water molecule. $[7,37,44,46]$ The following PCET event from species $\mathbf{S}_{3}$ requires an applied potential of $0.26 \mathrm{~V}$, and yields the intermediate $\left[\mathrm{Co}^{\mathrm{III}}(\mathrm{OOH}) \mathrm{Co}_{3}{ }^{\mathrm{II}}\left(\mathrm{H}_{2} \mathrm{O}\right)\left(\mathrm{PW}_{9} \mathrm{O}_{34}\right)_{2}\right]^{10-}$ $\left(\mathrm{S}_{3}\right)$, the ground state of which has nine unpaired electrons (three electrons on each $\mathrm{Co}^{\mathrm{II}}$ centers and a low-spin $\mathrm{Co}^{\mathrm{III}}$ ion) (see Figure 6).

The last PCET event requires a relatively low energy of $0.05 \mathrm{~V}$, and leads to the formation of the $\mathrm{Co}^{\mathrm{II}}$-OO $\left(\mathbf{S}_{4}\right)$ species with ten unpaired electrons, only one of which is localized in the reactive cobalt center. The last step involves the molecular oxygen released from species $\mathbf{S}_{4}$ upon coordination of another water molecule that regenerates the catalyst. Thus, based on above presented data, if the $\mathrm{Co}^{\mathrm{III}}-\mathrm{O}^{\circ}$ species $\left(\mathbf{S}_{\mathbf{2}}\right)$ has been formed (via either chemically or electrochemically or photochemically), then the following $\mathrm{O}-\mathrm{O}$ bond formation would occur with less energy demand.

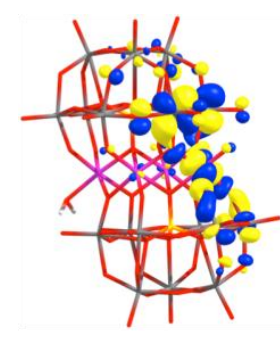

LUMO

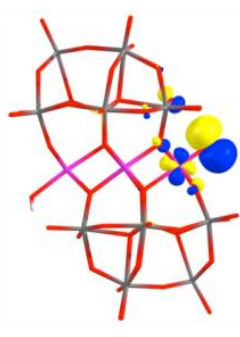

LUMO+1

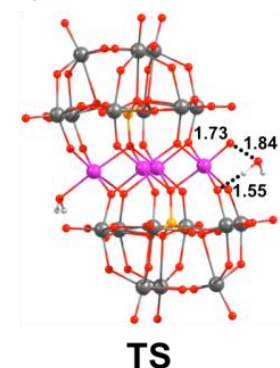

TS
Figure 7. LUMO and LUMO+1 orbital of the $\left[\mathrm{Co}^{\mathrm{III}}\left(\mathrm{O}^{*}\right) \mathrm{Co}_{3}{ }^{\text {II }}\left(\mathrm{H}_{2} \mathrm{O}\right)\left(\mathrm{PW}_{9} \mathrm{O}_{34}\right)_{2}\right]^{10-}\left(\mathbf{S}_{\mathbf{2}}\right)$ species, as well as transition state structure associated by water nucleophilic attack to $\left[\mathrm{Co}^{\mathrm{II}}(\mathrm{O})\left(\mathrm{H}_{2} \mathrm{O}\right) \mathrm{Co}_{3}{ }^{\mathrm{II}}\left(\mathrm{H}_{2} \mathrm{O}\right)\left(\mathrm{PW}_{9} \mathrm{O}_{34}\right)_{2}\right]^{10-}$ (TS); distances are given in $\AA$.

One should mention that some of previous studies have proposed the water molecules of solvation shells to be a proton acceptor, but our studies of $\mathbf{P C o}_{4}$ show that the bridging oxygen of the $\mathrm{Co}-\mathrm{O}-\mathrm{W}$ moiety is the favored proton acceptor,[40, 45, 61-63] similar to the situation proposed in the Ru-substituted Keggin anions.[46]

Thus, above presented data show that $\mathbf{P C o}_{4}$ catalyzed water oxidation starts with the sequential $\mathrm{ET}+\mathrm{PT} \quad$ event $\quad\left[\mathbf{S}_{\mathbf{0}}\left(\mathrm{Co}^{\mathrm{II}}-\mathrm{OH}_{2}\right) \rightarrow \mathbf{S}_{\mathbf{1}}{ }^{\prime} \rightarrow \mathbf{S}_{\mathbf{1}}\left(\mathrm{Co}^{\mathrm{III}}-\mathrm{OH}\right)\right]$ followed by the formation of the reactive $\mathrm{S}_{2}\left(\mathrm{Co}^{\text {III }}\right.$ $\left.\mathrm{O}^{*}\right)$ species via the PCET event $\left[\mathbf{S}_{\mathbf{1}}\left(\mathrm{Co}^{\mathrm{III}}\right.\right.$ $\left.\mathrm{OH}) \rightarrow \mathbf{S}_{\mathbf{2}}\left(\mathrm{Co}^{\mathrm{III}}-\mathrm{O}^{\circ}\right)\right]$. The $\mathbf{S}_{\mathbf{2}}\left(\mathrm{Co}^{\mathrm{III}}-\mathrm{O}^{*}\right)$ intermediate reacts with an external water molecule then two subsequent PCETs result in the formation of molecular $\mathrm{O}_{2}$. In this mechanism, the $\mathrm{S}_{\mathbf{1}}\left(\mathrm{Co}^{\mathrm{III}}\right.$ $\mathrm{OH}) \rightarrow \mathbf{S}_{\mathbf{2}}\left(\mathrm{Co}^{\mathrm{III}}-\mathrm{O}^{*}\right)$ step determines the potential 
required for the formation of the active species.[59] As shown above, the electrochemical generation of the active species $\mathbf{S}_{\mathbf{2}}\left(\mathrm{Co}^{\mathrm{III}}-\mathrm{O}^{*}\right)$ formation requires $1.48 \mathrm{~V}$ of applied potential at $\mathrm{pH}=8$, which would correspond to an overpotential of $0.72 \mathrm{~V}$. [Note that overpotential $(\eta)$ is simply the difference between $\Delta \mathrm{G}\left(\mathbf{S}_{1} \rightarrow \mathbf{S}_{2}\right)$ and $\left.\Delta \mathrm{G}\left(2 \mathrm{H}_{2} \mathrm{O} \rightarrow \mathrm{O}_{2}+2 \mathrm{H}_{2}\right) / 4\right]$. As already mentioned, WOC reactions are frequently facilitated photochemically. Formally, electrochemical and photochemical processes are rather similar, but energetic balance requires consideration of the oxi-reduction of the sacrificial electron acceptor.

On the other hand, the kinetics of the chemical $\mathrm{O}-\mathrm{O}$ bond formation is determined by the $\mathrm{O}-\mathrm{O}$ bond formation transition state. This reaction step requires an energy of $22.8 \mathrm{kcal} \cdot \mathrm{mol}^{-1}(0.99 \mathrm{eV})$, which is clearly accessible at room temperature when the applied potential is positive enough to shift the pre-equilibria toward the reactive $\mathrm{Co}^{\mathrm{III}}-\mathrm{O}^{\circ}$ species $\left(\mathbf{S}_{\mathbf{2}}\right)$.

Comparison of these findings for $\mathbf{P C} \mathbf{o}_{4}$ catalyst with those for the previously studied $\mathrm{Ru}^{\mathrm{III}}$ based catalysts (both those in organometallic and POM frameworks) shows that oxidation of Ru centers occurs at lower potentials than Co center. Indeed, the one-electron oxidation potential for $\left[\mathrm{Ru}^{\mathrm{III}}\left(\mathrm{H}_{2} \mathrm{O}\right) \mathrm{SiW}_{11} \mathrm{O}_{39}\right]^{5-}$ was reported to be $0.64 \mathrm{~V}$ vs. SCE (o.88 V vs NHE), [67] while its computed value was $0.45 \mathrm{~V}$.[46] For the $\mathrm{Ru}_{4}-\mathrm{POM}$, $\left[\mathrm{Ru}_{4} \mathrm{O}_{4}(\mathrm{OH})_{2}\left(\mathrm{H}_{2} \mathrm{O}\right)_{4}\left(\gamma-\mathrm{SiW}_{10} \mathrm{O}_{36}\right)_{2}\right]^{10-}$, the PCET event leading to the formation of active $\mathrm{Ru}^{\mathrm{V}}-\mathrm{O}$ species is reported to require $1.53 \mathrm{~V}$ potential (at $\mathrm{pH}$ $=0), 400 \mathrm{mV}$ lower than the potential we have found for $\mathbf{P C} \mathbf{o}_{4}$. [45] In contrast, the energy for the $\mathrm{O}-\mathrm{O}$ bond formation was reported to be rather high in $\left[\mathrm{Ru}^{\mathrm{III}}\left(\mathrm{H}_{2} \mathrm{O}\right) \mathrm{SiW}_{11} \mathrm{O}_{39}\right]^{5^{-}} \quad\left(\begin{array}{llll}1.23 & \mathrm{eV}, & 28.4\end{array}\right.$ $\left.\mathrm{kcal} \cdot \mathrm{mol}^{-1}\right) \cdot[46]$

Indeed, it is worth mentioning that TOF values measured for tetraruthenium and $\mathbf{P C o}_{4}$ anions indicate a higher catalytic activity for $\mathbf{P C o}_{4}$ suggesting a lower free energy barrier for the latter.[24]

3. Water oxidation catalyzed by the $\mathrm{VCo}_{4}$ polyoxometalate. As explained above, the replacement of $\mathrm{P}^{\mathrm{V}}$ in $\mathbf{P C o}_{4}$ by $\mathrm{V}^{\mathrm{V}}$ results in the $\left[\mathrm{Co}_{4}\left(\mathrm{H}_{2} \mathrm{O}\right)_{2}\left(\mathrm{VW}_{9} \mathrm{O}_{34}\right)_{2}\right]^{10-}\left(\mathbf{V C o}_{4}\right)$ anion, which exhibits a greater hydrolytic stability than $\mathbf{P C o}_{4}$. Furthermore, $\mathbf{V C o}_{4}$ is a relatively faster water oxidation catalyst than $\mathbf{P C o}_{4}$ under photochemical conditions.[6o] Such a change in stability and reactivity of the catalyst upon going from $\mathbf{P C o}_{4}$ to $\mathbf{V C o}_{4}$ likely reflects the differences in electronic structure of the two POMs, despite the fact that both $\mathbf{P C o _ { 4 }}$ and $\mathbf{V C o _ { 4 }}$ have a same overall charge and nearly identical geometries.[32, 33, 6o] This statement is partly supported by the UV-vis spectra that show transitions involving orbitals of cobalt and heteroatom (vanadium) for $\mathbf{V C o}_{4}$, whereas these transitions do not appear for the $\mathbf{P C o}_{4}$. This finding indicates involvement of vanadium $\mathrm{d}$ orbitals in redox chemistry of $\mathbf{V C o}_{4} \cdot[6 \mathrm{o}]$

In order to provide computational support and elucidate additional factors explaining the difference in stability and reactivity of $\mathbf{P C} \mathbf{o}_{4}$ and $\mathbf{V C o}_{4}$ systems, we also computed the water oxidation mechanism for the $\mathbf{V C o}_{4}$ system and compared the resulting data with that for the $\mathbf{P C} \mathbf{o}_{4}$ system.

As reported previously, the calculated geometry and the corresponding X-ray crystallographic values for $\mathbf{P C o}_{4}$ and $\mathbf{V C o}_{4}$ are in close agreement. Meanwhile, there exist several remarkable differences (see Table 1) in the calculated energy values of the analogous steps of the $\mathrm{PCo}_{4}{ }^{-}$and $\mathrm{VCo}_{4}$-catalyzed water oxidation cycles. The most significant differences are in: (a) the increase of the potential for oxidation of $\mathrm{Co}^{\mathrm{II}}$-center to the Co ${ }^{\mathrm{III}}$ one $\left(\mathbf{S}_{\mathbf{o}} \rightarrow \mathbf{S}_{1}{ }^{\prime}\right)$, and (b) the reduction of the energy barrier upon the nucleophilic attack of water on the $\mathrm{Co}^{\mathrm{III}}$-oxyl group $\left(\mathbf{S}_{\mathbf{2}} \rightarrow \mathbf{T S}\right)$. Indeed, the $\mathbf{S}_{\mathbf{0}} \rightarrow \mathbf{S}_{\mathbf{1}}^{\prime}$ transition for $\mathrm{VCo}_{4}$ requires a $1.58 \mathrm{~V}$ of applied potential, which is a 0.31 $\mathrm{V}$ larger than that required for $\mathbf{P C o}_{4}$. These differences for the $\mathbf{P C o}_{4}$ and $\mathbf{V C o} \mathbf{O}_{4}$ systems could be explained by coupling of $\mathrm{d}$ orbitals of $\mathrm{V}$ and $\mathrm{Co}$ atoms in $\mathbf{V C o}_{4}$ which results in stabilization of the $e_{g}$-type electrons of the Co(II) center in $\mathbf{S}_{\mathbf{o}}$ state, and increases in oxidation potential of $\mathrm{Co}$ (II)-center to give the low-spin $\mathbf{C o}$ (III) center in $\mathbf{S}_{\mathbf{1}}{ }^{\prime}$ state without $e_{g}$-type electrons. This also confers an additional structural stability to $\mathbf{V C o}_{4}$ during catalytic turnover. Because of the complexity of the systems and the extensive delocalization electrons in canonical orbitals a simple examination of the occupied molecular orbitals in the $\mathbf{S}_{\mathbf{o}}$ state does not permit to identify a unique (or a few number) orbital(s) that recovers the coupling between $\mathrm{V}$ and Co orbitals. However, unoccupied orbitals are usually much more localized and thanks to that the $\mathrm{V}$ - Co coupling in $e_{g}$-type orbitals has been characterized in the parent $\mathbf{S}_{\mathbf{1}}{ }^{\prime}$ species. A detailed description is provided in the SI (Figure $\mathrm{S}_{1}$ ).

One should emphasize that, although the $\mathrm{Co}^{\mathrm{II}} / \mathrm{Co}^{\mathrm{III}}$ (i.e. $\mathbf{S}_{\mathbf{0}} \rightarrow \mathbf{S}_{\mathbf{1}}{ }^{\prime}$ step) oxidation potential increases upon going from $\mathbf{P C o}_{4}$ to $\mathbf{V C o}_{4}$, this change is not expected to have significant influence to the overall catalytic performance of the $\mathrm{Co}_{4}$ POM systems since the step that determines the overpotential $\left(\mathbf{S}_{\mathbf{1}} \rightarrow \mathbf{S}_{\mathbf{2}}\right.$ step) appears later in the catalytic cycle. 
Once the species $\left(\mathbf{S}_{\mathbf{o}}\right)$ with all-Co ${ }^{\text {II }}$ centers is oxidized to the species $\left(\mathbf{S}_{\mathbf{1}}{ }^{\prime}\right)$ with three $\mathrm{Co}^{\mathrm{II}}$ and one $\mathrm{Co}^{\text {III }}$ centers, the next two events in the water oxidation cycle do not directly involve the active Co center. As a consequence, the energy required for the following steps is not expected to be dramatically different for the $\mathbf{P C o}_{4}$ and $\mathbf{V C o}_{4}$ catalysts. Indeed, our calculations show that: (a) the deprotonation $\left(\mathbf{S}_{\mathbf{1}}{ }^{\prime} \rightarrow \mathbf{S}_{\mathbf{1}}\right)$ requires a slightly higher energy $\left(7.4 \mathrm{kcal} \cdot \mathrm{mol}^{-1}, 0.32 \mathrm{eV}\right)$ for $\mathbf{V C o}_{4}$ than for $\mathbf{P C o}_{4}\left(5.5 \mathrm{kcal} \cdot \mathrm{mol}^{-1}, 0.24 \mathrm{eV}\right)$; and (2) the second PCET event $\left(\mathbf{S}_{\mathbf{1}} \rightarrow \mathbf{S}_{\mathbf{2}}\right)$ is only $+0.14 \mathrm{~V}$ higher in energy for $\mathbf{V C o}_{4}$ than for $\mathbf{P C o}_{4}$ (Table 1).

As outlined above, the following step in the $\mathrm{Co}_{4}$ POM-catalytized water oxidation cycle is $\mathrm{O}-\mathrm{O}$ bond formation initiated by the nucleophilic attack of external water on the $\mathrm{Co}^{\mathrm{III}}$-oxyl group. The computed activation free energy for $\mathbf{V C o}_{4}(16.8$ $\left.\mathrm{kcal} \cdot \mathrm{mol}^{-1}, 0.73 \mathrm{eV}\right)$ is about $6 \mathrm{kcal} \cdot \mathrm{mol}^{-1}(0.26 \mathrm{eV})$ lower than that found for the $\mathbf{P C o}_{4}$ anion, see Figure 8 . Thus, if the active $\mathrm{Co}^{\mathrm{III}}$-oxyl intermediate is already formed by various means, such as electrochemical, photo-induced or chemical pathways, then the $\mathrm{O}-\mathrm{O}$ bond formation is expected to be faster for $\mathbf{V C o}_{4}$ than for $\mathbf{P C o}_{4}$. This conclusion qualitatively agrees with the observed kinetic behavior reported by Hill and co-workers, who have shown that $\mathbf{V C o}_{4}$ displays faster kinetics than $\mathbf{P C o}_{4}$. While the trend is well reproduced, the computed absolute values of the free energy barriers (16.8 and $22.8 \mathrm{kcal} \cdot \mathrm{mol}^{-1}$ for $\mathbf{V C o}_{4}$ and $\left.\mathbf{P C o}_{4}\right)$ are somewhat higher than those estimated from experimental TOFs (13 and $16 \mathrm{kcal} \cdot \mathrm{mol}^{-1}$, respectively). However, if we consider the overestimation of entropy penalty for these biomolecular processes, the calculations are in reasonable good agreement with observations (see Table $S_{5}$ in the Supporting Information). All these results are consistent with the fact that the $\mathrm{O}-\mathrm{O}$ bond formation step might be the turnoverlimiting chemical step, after the formation of the catalytic active $\mathrm{Co}^{\mathrm{III}}$-oxyl intermediate.[73]

In order to elucidate reason of the aforementioned reduction of the $\mathrm{O}-\mathrm{O}$ bond formation barrier upon going from $\mathbf{P C o}_{4}$ to $\mathbf{V C o}_{4}$, we analyzed a set of lowest unoccupied orbitals of their $\mathbf{S}_{2}$ species, because these could be the acceptor orbitals in the nucleophilic attack of water. For $\mathbf{P C o}_{4}$, we found that LUMO and LUMO+1 orbitals have $-2.88 \mathrm{eV}$ and $-2.75 \mathrm{eV}$ energies, respectively. Among these orbitals, the LUMO+1 has a strong $\mathrm{p}$ (oxyl) contribution and, therefore, is the best candidate to accept electrons from the coordinated water molecule (see Figure 7). However, in the case of $\mathbf{V C o}_{4}$, three unoccupied orbitals, namely, LUMO, LUMO+1 and LUMO+2 orbitals, have a strong contribution from the oxyl oxygen (Figure 9) and are good candidates for being an acceptor orbitals. Interestingly, all these three orbitals are lie lower in energy (at the positions of $-2.95 \mathrm{eV},-2.78 \mathrm{eV}$ and $-2.77 \mathrm{eV}$, respectively) than the LUMO and $L U M O+1$ orbitals of the $\mathbf{S}_{2}$ species of $\mathbf{P C o}_{4}$. Therefore, one may expect attack of water molecule to the $\mathbf{S}_{2}$ species to be more favorable for $\mathbf{V C o}_{4}$ than for $\mathbf{P C o}_{4}$.

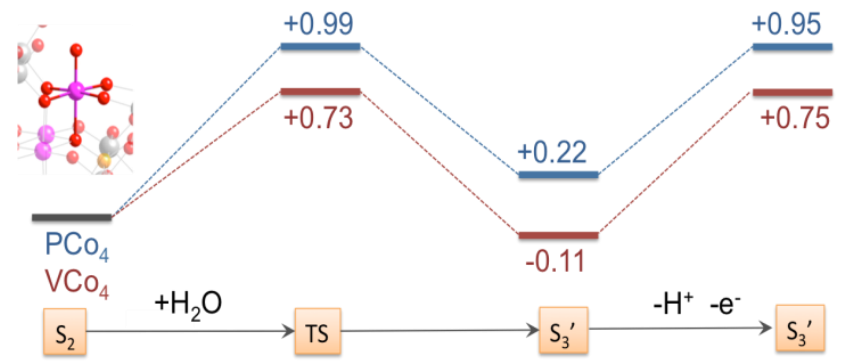

Figure 8. Energy profile corresponding to the water nucleophilic attack to $\mathrm{Co}^{\mathrm{III}}$-oxyl species $\left(\mathbf{S}_{\mathbf{2}}\right)$, and subsequent PCET event started from protonated $\mathrm{Co}^{\mathrm{II}}-\mathrm{OOH} \mathrm{POM}\left(\mathbf{S}_{\mathbf{3}}{ }^{\prime}\right)$ (energies are in $\mathrm{eV}$ )

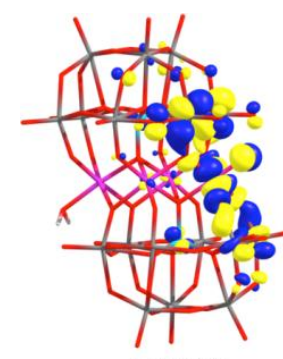

LUMO

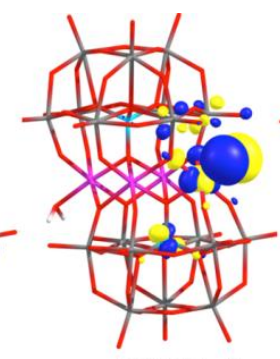

LUMO+1

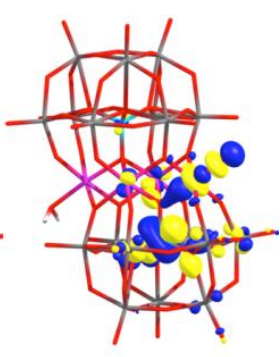

LUMO+2
Figure 9. LUMO, LUMO+1 and $\mathrm{LUMO}+2$ orbitals of the $\left[\mathrm{Co}^{\mathrm{III}}\left(\mathrm{O}^{\circ}\right) \mathrm{Co}_{3}{ }^{\mathrm{II}}\left(\mathrm{H}_{2} \mathrm{O}\right)\left(\mathrm{VW}_{9} \mathrm{O}_{34}\right)_{2}\right]^{10-}\left(\mathrm{S}_{2}\right)$ species.

\section{CONCLUSIONS}

From the above present computational studies we may conclude:

1. The initial H-atom removal step $\left[\mathrm{S}_{\mathbf{o}}\left(\mathrm{POM}-\mathrm{Co}^{\mathrm{II}}-\right.\right.$ $\left.\left.\mathrm{OH}_{2}\right) \rightarrow \mathbf{S}_{1}\left(\mathrm{POM}-\mathrm{Co}^{\mathrm{III}}-\mathrm{OH}\right)\right]$ in water oxidation catalyzed by the $\mathbf{P C o}_{4}$ and $\mathbf{V C o}_{4}$ anions could proceed via the uncoupled electron-thenproton transfer $(\mathrm{ET}+\mathrm{PT})$ pathway and leads to one-electron oxidize species $\mathbf{S}_{\mathbf{1}}$. Although we cannot discard the concerted PCET event being competitive with the ET+PT pathway when the applied potential is held high enough, since both processes are relatively close in energy. The second $\mathrm{H}$-atom removal from the $\mathrm{OH}$ fragment of $\mathbf{S}_{\mathbf{1}}$ is a concerted PCET event and forms the $\mathrm{Co}^{\text {III }}-\mathrm{O}^{*}$ active species $\mathbf{S}_{2}$. The overall $\mathbf{S}_{\mathbf{0}} \rightarrow \mathbf{S}_{\mathbf{2}}$ transformation is estimated to require less than $1.48 \mathrm{~V}$ and $1.62 \mathrm{~V}$ at $\mathrm{pH}=8$ for $\mathbf{P C o}_{4}$ and $\mathbf{V C o}_{4}$ anions, respectively, which determine the overpotential for the overall catalytic reaction.[59]

2. The $\mathrm{O}-\mathrm{H}$ bond cleavage (i.e. $\mathbf{S}_{\mathbf{1}} \boldsymbol{\rightarrow}_{\boldsymbol{B}} \mathbf{S}_{\mathbf{1}}$ step) together with the $\mathrm{O}-\mathrm{O}$ bond formation, i.e. the 
chemical steps of the reaction, control the kinetics of the reaction. Where the $\mathrm{O}-\mathrm{O}$ bond formation occurs via a "water nucleophilic attack" mechanism from the $\mathrm{Co}^{\mathrm{III}}$-oxyl intermediate $\mathbf{S}_{2}$, which requires $22.8 \mathrm{kcal} \cdot \mathrm{mol}^{-1}$ $(0.99 \mathrm{eV})$ and $16.8 \mathrm{kcal} \cdot \mathrm{mol}^{-1}(0.73 \mathrm{eV})$ energy barriers for $\mathbf{P C o}_{4}$ and $\mathbf{V C o}_{4}$, respectively.

3. Comparison of the calculated energetics for the $\mathbf{P C o}_{4}$ and $\mathbf{V C o}_{4}$ anions shows that coupling of $\mathrm{d}$ orbitals of $\mathrm{V}$ and $\mathrm{Co}$ atoms in $\mathbf{V C o}_{4}$ results in stabilization of high-spin $\mathrm{Co}$ (II)-centers with $e_{g}$-type electrons compared to the low-spin Co(III)-centers. Orbital coupling is also predicted to be reason (or one of reasons) for observed enhancement of catalytic activity of $\mathbf{V C o}_{4}$ compared to $\mathbf{P C o}_{4}$.

In summary, using a relatively simple model system we have been able to propose a plausible reaction mechanism for Co-containing POM acting as WOCs. We are convinced that in the years to come the combination of additional experimental data with more sophisticated models that consider, for example, the effect of the buffer, ionic strength, or the incorporation of explicit waters in some steps will allow to advance further in understanding of these complex catalytic reactions.

Computational Details. All reported calculations were performed with the Gaussian-og package[74] at density functional theory (DFT) level by utilizing B3LYP functional.[75-77] Recently, Fabris et al. have shown that exchange-correlation hybrid functionals such as the B 3 LYP and the PBEo lead to a fair agreement with the coupled cluster energies for the water oxidation process by cobalt oxide clusters.[78] In fact, latter successful computational studies on WOC process by $\mathrm{Co}$ systems employed B3LYP functional.[56, 58] This latter functional has been widely used in theoretical studies of TM substituted polyoxometalates.[72],[79-82]

For $\mathrm{P}, \mathrm{Co}$ and $\mathrm{W}$ atoms, the LANL2DZ effective core potential (ECP) and associated basis sets were used.[83] The 6-31G $(\mathrm{d}, \mathrm{p})$ basis set was used for $\mathrm{O}$ atoms directly bound to $\mathrm{Co}$ and the $6-31 \mathrm{G}$ basis set for the rest of atoms. [84-86] All the structures were optimized in water using IEF-PCM approach to model the solvent effects $(\varepsilon=78.36$ and UFF radii). [87] The nature of all stationary points was verified by vibrational frequencies, which were also used for calculation of free energy contributions. A data set collection of computational results is available in the ioChem-BD repository[88] and can be accessed via doi10.19061/iochem-bd-2-6.
In order to investigate the energies required to reach each step in the catalytic cycle we adopted the energetic scheme proposed by Voorhis:[43]

$$
\mathrm{E}^{0}=\frac{1}{\mathrm{~F}}\left(\Delta \mathrm{G}_{(\mathrm{g})}^{0}+\Delta \mathrm{G}_{\mathrm{solv}}-\mathrm{n}_{\mathrm{H}^{+}} \mathrm{G}_{(\mathrm{aq})}^{0 \mathrm{H}^{+}}\right)-4.24 \mathrm{~V}(\mathrm{1})
$$

where $\mathrm{F}$ is the Faraday constant, $\Delta G_{(g)}^{0}$ is the free energy change associated with oxidation in vacuum, $\Delta G_{\text {solv }}$ is the free energy of solvation, $G_{(a q)}^{O H^{+}}$is the standard free energy of a proton in aqueous solution for which we adopted a value of $-11.803 \mathrm{eV}$, the negative term $\left(\mathrm{E}_{\mathrm{abs}}^{*}=-4.24 \mathrm{~V}\right)$ is the absolute standard potential of the half-reaction:

$$
\mathrm{H}^{+}{ }_{(\mathrm{aq})}+\mathrm{e}_{(\mathrm{g})}^{-} \longleftrightarrow 1 / 2 \mathrm{H}_{2(\mathrm{~g})}
$$

For elementary electrochemical steps that involve a proton transfer, the measured potential at experimental $\mathrm{pH}$ conditions is related to standard conditions $(\mathrm{pH}=\mathrm{o})$ by the Nernst equation that a room temperature is (in $\mathrm{V}$ )

$\mathrm{E}=\mathrm{E}^{0}-0.059 * \mathrm{pH}(2)$

Calculated $\mathrm{pK}_{\mathrm{a}}$ values were obtained from the free energy of deprotonation steps using the standard equation:[89, 9o]

$\mathrm{pK}_{\mathrm{a}}=-\log _{10} \mathrm{e}^{-\Delta \mathrm{G}_{\mathrm{a}(\mathrm{s})} / \mathrm{RT}}$

\section{ASSOCIATED CONTENT}

Supporting Information. Electronic and free energies, configurations, charges, and multiplicities, as well as atomic spin densities, and cartesian coordinates of all the computed structures of the catalytic cycle.

\section{AUTHOR INFORMATION}

\section{Corresponding Author}

* josepmaria.poblet@urv.cat; j.carbo@urv.cat: dmusaev@emory.edu

\section{Author Contributions}

All authors have given approval to the final version of the manuscript.

\section{ACKNOWLEDGMENT}

We thank the Spanish Ministry of Science and Innovation (grant CTQ2014-52774-P), the DGR of the Generalitat de Catalunya (grant 2014SGRig9 and XRQTC). We thank also CMST COST Action CM1203. J.M.P. thanks ICREA foundation for an ICREA ACADEMIA award for research excellence. D.G.M. and C.L.H. are acknowledging U.S. Department of Energy, Office of Basic Energy Sciences, Solar Photochemistry Program (DE-FGo2-07ER-15906) for support, as well as NSF MRI-R2 grant (CHE-0958205) and the use of the resources of the Cherry Emerson Center for Scientific Computation. We are very grateful to referees for their helpful comments. 


\section{REFERENCES}

[1] N.S. Lewis, D.G. Nocera, Proc. Natl. Acad. Sci., 103 (2006) 15729-15735.

[2] V. Balzani, A. Credi, M. Venturi, ChemSusChem, 1 (2008) 2658.

[3] H. Dau, C. Limberg, T. Reier, M. Risch, S. Roggan, P. Strasser, ChemCatChem, 2 (2010) 724-761.

[4] X. Liu, F.Y. Wang, Coord. Chem. Rev., 256 (2012) 1115-1136.

[5] D.J. Wasylenko, R.D. Palmer, C.P. Berlinguette, Chem. Commun., 49 (2013) 218-227.

[6] J.J. Concepcion, J.W. Jurss, M.K. Brennaman, P.G. Hoertz, A.O.T. Patrocinio, N.Y. Murakami Iha, J.L. Templeton, T.J. Meyer, Acc. Chem. Res., 42 (2009) 1954-1965.

[7] Y. Jiang, F. Li, B. Zhang, X. Li, X. Wang, F. Huang, L. Sun, Angew. Chem. Int. Ed., 52 (2013) 3398-3401.

[8] J.D. Blakemore, N.D. Schley, D. Balcells, J.F. Hull, G.W. Olack, C.D. Incarvito, O. Eisenstein, G.W. Brudvig, R.H. Crabtree, J. Am. Chem. Soc., 132 (2010) 16017-16029.

[9] L. Duan, F. Bozoglian, S. Mandal, B. Stewart, T. Privalov, A. Llobet, L. Sun, Nat. Chem., 4 (2012) 418-423.

[10] J. Lloret-Fillol, Z. Codolà, I. Garcia-Bosch, L. Gómez, J.J. Pla, M. Costas, Nat. Chem., 3 (2011) 807-813.

[11] R. Lalrempuia, N.D. McDaniel, H. Müller-Bunz, S. Bernhard, M. Albrecht, Angew. Chem. Int. Ed., 49 (2010) 9765-9768.

[12] S.M. Barnett, K.I. Goldberg, J.M. Mayer, Nat. Chem., 4 (2012) 498-502.

[13] D.J. Wasylenko, C. Ganesamoorthy, J. Borau-Garcia, C.P. Berlinguette, Chem. Commun., 47 (2011) 4249-4251.

[14] N.S. McCool, D.M. Robinson, J.E. Sheats, G.C. Dismukes, J. Am. Chem. Soc., 133 (2011) 11446-11449.
[15] M.-T. Zhang, Z. Chen, P. Kang, T.J. Meyer, J. Am. Chem. Soc., 135 (2013) 2048-4051.

[16] C. Sens, I. Romero, M. Rodríguez, A. Llobet, T. Parella, J. Benet-Cuchholz, J. Am. Chem. Soc., 126 (2004) 7798-7799.

[17] F. Bozoglian, S. Romain, M.Z. Ertem, T.K. Todorova, C. Sens, J. Mola, M. Rodríguez, I. Romero, J. Benet-Buchholz, X. Fontrodona, C.J. Cramer, L. Gagliardi, A. Llobet, J. Am. Chem. Soc., 131 (2009) 15176-15187.

[18] J.J. Concepcion, J.W. Jurss, J.L. Templeton, T.J. Meyer, J. Am. Chem. Soc., 130 (2008) 16462-16463.

[19] Y. Xu, A. Fischer, L. Duan, L. Tong, E. Gabrielsson, B. Åkermark, L. Sun, Angew. Chem. Int. Ed., 49 (2010) 8934-8937.

[20] M.T. Pope, A. Müller, Polyoxometalate Chemistry: From Topology via self-Assembly to Applications, Springer, New York, 2001.

[21] L. Cronin, A. Müller, Chem. Soc. Rev., 41 (2012) 7333-7334.

[22] J.J. Stracke, R.G. Finke, ACS Catal., 4 (2014) 909-933.

[23] R. Schiwon, K. Klingan, H. Dau, C. Limberg, Chem. Commun., 50 (2013) 100-102.

[24] H. Lv, Y.V. Geletii, C. Zhao, J.W. Vickers, G. Zhu, Z. Luo, J. Song, T. Lian, D.J. Musaev, C.L. Hill, Chem. Soc. Rev., 41 (2012) 7572-7589.

[25] S. Goberna-Ferrón, J. Soriano-López, J.R. Galán-Mascarós, M. Nyman, Eur. J. Inorg. Chem., 2015 (2015) 2833-2840.

[26] A. Sartorel, M. Carraro, G. Scorrano, R. De Zorzi, S. Geremia, N.D. McDaniel, S. Bernhard, M. Bonchio, J. Am. Chem. Soc., 130 (2008) 5006-5007.

[27] A. Sartorel, P. Miró, E. Salvarodi, S. Romain, M. Carraro, G. Scorrano, M. Di Valentin, A. Llobet, C. Bo, M. Bonchio, J. Am. Chem. Soc., 131 (2009) 16051-16053.

[28] F.M. Toma, A. Sartorel, M. Iurlo, M. Carraro, P. Parisse, C. Maccato, S. Rapino, B. Rodriguez-Gonzalez, H. Amenitsch, T. Da 
Ros, L. Casalis, A. Goldoni, M. Marcaccio, G. Scorrano, G. Scoles, F. Paolucci, M. Prato, M. Bonchio, Nat. Chem., 2 (2010) 826831.

[29] Y.V. Geletii, B. Botar, P. Koegerler, D.A. Hillesheim, D.G. Musaev, C.L. Hill, Angew. Chem. Int. Ed., 47 (2008) 3896-3899.

[30] Y.V. Geletii, Z. Huang, Y. Hou, D.G. Musaev, T. Lian, C.L. Hill, J. Am. Chem. Soc., 131 (2009) 7522-7523.

[31] C. Besson, Z. Huang, Y.V. Geletii, S. Lense, K.I. Hardcastle, D.G. Musaev, T. Lian, A. Proust, C.L. Hill, Chem. Commun., 46 (2010) 2784-2786.

[32] Q. Yin, J.M. Tan, C. Besson, Y.V. Geletii, D.G. Musaev, A.E. Kuznetsov, Z. Luo, K.I. Hardcastle, C.L. Hill, Science, 328 (2010) $342-345$.

[33] J.W. Vickers, H. Lv, M. Sumliner, G. Zhu, Z. Luo, D.G. Musaev, Y.V. Geletii, C.L. Hill, J. Am. Chem. Soc., 135 (2013) 14110-14118.

[34] S. Goberna-Ferrón, L. Vigara, J. Soriano-López, J.R. GalánMascarós, Inorg. Chem., 51 (2012) 11707-11715.

[35] J. Soriano-López, S. Goberna-Ferrón, L. Vigara, J.J. Carbó, J.M. Poblet, J.R. Galán-Mascarós, Inorg. Chem., 52 (2013) 47534755.

[36] M.W. Kanan, D.G. Nocera, Science, 321 (2008) 1072-1075.

[37] S. Goberna-Ferrón, B. Peña, J. Soriano-López, J.J. Carbó, H. Zhao, J.M. Poblet, K.R. Dunbar, J.R. Galán-Mascarós, J. Catal., 315 (2014) 25-32.

[38] R. Kang, K. Chen, J. Yao, S. Shaik, H. Chen, Inorg. Chem., 53 (2014) 7130-7136.

[39] M. Hirahara, M.Z. Ertem, M. Komi, H. Yamazaki, C.J. Cramer, M. Yagi, Inorg. Chem., 52 (2013) 6354-6364.

[40] L. Vigara, M.Z. Ertem, N. Planas, F. Bozoglian, N. Leidel, H. Dau, M. Haumann, L. Gagliardi, C.J. Cramer, A. Llobet, Chem. Sci., 3 (2012) 2576-2586
[41] S. Roeser, M.Z. Ertem, C. Cady, R. Lomoth, J. BenetBuchholz, L. Hammarström, B. Sarkar, W. Kaim, C.J. Cramer, A. Llobet, Inorg. Chem., 51 (2012) 320-327.

[42] J.J. Concepcion, M.-K. Tsai, J.T. Muckerman, T.J. Meyer, J. Am. Chem. Soc., 132 (2010) 1545-1557.

[43] L.-P. Wang, Q. Wu, T. Van Voorhis, Inorg. Chem., 49 (2010) $4543-4553$.

[44] X. Sala, M.Z. Ertem, L. Vigara, T.K. Todorova, W. Chen, R. C., R.C. Rocha, F. Aquilante, C.J. Cramer, L. Gagliardi, A. Llobet, Angew. Chem. Int. Ed., 49 (2010) 7745-7747.

[45] S. Piccinin, A. Sartorel, G. Aquilanti, A. Goldoni, M. Bonchio, S. Fabris, Proc. Natl. Acad. Sci., 110 (2013) 4917-4922.

[46] L. Z-L., G.-C. Yang, N.-N. Ma, S.-Z. Wen, L.-K. Yan, W. Guan, Z.-M. Su, Dalton. Trans., 42 (2013) 10617-10625.

[47] S. Piccinin, S. Fabris, Phys. Chem. Chem. Phys., 13 (2011) 7666-7674.

[48] A.E. Kuznetsov, Y.V. Geletii, C.L. Hill, K. Morokuma, D.G. Musaev, Theor. Chem. Acc., 130 (2011) 197-207.

[49] D. Quiñonero, A.L. Kaledin, A.E. Kuznetsov, Y.V. Geletii, C. Besson, C.L. Hill, D.G. Musaev, J. Phys. Chem. A, 114 (2010) 535542.

[50] A.E. Kuznetsov, Y.V. Geletii, C.L. Hill, K. Morokuma, D.G. Musaev, J. Am. Chem. Soc., 131 (2009) 6844-6854.

[51] S. Piccinin, S. Fabris, Inorganics, 3 (2015) 374-387.

[52] L.-P. Wang, T. Van Voorhis, J. Phys. Chem. Lett., 2 (2011) 2200-2204.

[53] X. Li, P.E.M. Siegbahn, J. Am. Chem. Soc., 135 (2013) $13804-13813$.

[54] J.G. McAlpin, T.A. Stich, C.A. Ohlin, Y. Surendranath, D.G. Nocera, W.H. Casey, R.D. Britt, J. Am. Chem. Soc., 133 (2011) $15444-15452$ 
[55] G. Mattioli, P. Giannozzi, A.A. Bonapasta, L. Guidoni, J. Am. Chem. Soc., 135 (2013) 15353-15363.

[56] A. Fernando, C.M. Aikens, J. Phys. Chem., 119 (2015) 11072-11085.

[57] M. Bajdich, M. García-Mota, A. Vojvodic, J.K. Nørskov, A.T. Bell, J. Am. Chem. Soc., 135 (2013) 13521-13530.

[58] F.H. Hodel, S. Luber, ACS Catal., 6 (2016) 1505-1517.

[59] M.G. Mavros, T. Tsuchimochi, T. Kowalczyk, A. Mclssac, L.-

P. Wang, T. Van Voorhis, Inorg. Chem., 53 (2014) 6386-6397.

[60] H. Lv, J. Song, Y.V. Geletii, J.W. Vickers, J.M. Sumliner, D.G. Musaev, P. Koegerler, P.F. Zhuk, J. Bacsa, G. Zhu, C.L. Hill, J. Am. Chem. Soc., 136 (2014) 9268-9271.

[61] H. Lei, A. Han, F. Li, M. Zhang, Y. Han, P. Du, W. Lai, R. Cao, Phys. Chem. Chem. Phys., 16 (2014) 1883-1893.

[62] W. Lai, R. Cao, G. Dong, S. Shaik, J. Yao, H. Chen, J. Phys. Chem. Lett., 3 (2012) 2315-2319.

[63] M.Z. Ertem, C.J. Cramer, Dalton. Trans., 41 (2012) 1221312219.

[64] C.A. Ohlin, S.J. Harley, J.G. McAlpin, R.K. Hocking, B.Q. Mercado, R.L. Johnson, E.M. Villa, M.K. Fidler, M.M. Olmstead, L. Spiccia, R.D. Britt, W.H. Casey, Chem. Eur. J., 17 (2011) 44084417.

[65] D. Lieb, A. Zahl, E.F. Wilson, C. Streb, L.C. Nye, K. Meyer, I. Ivanović-Burmazović, Inorg. Chem., 50 (2011) 9053-9058.

[66] J.J. Stracke, R.G. Finke, ACS Catal., 3 (2013) 1209-1219.

[67] M. Murakami, D. Hong, T. Suenobu, S. Yamaguchi, T. Ogura, S. Fukuzumi, J. Am. Chem. Soc., 133 (2011) 11605-11613.

[68] D. Barats-Damatov, L.J.W. Shimon, L. Weiner, R.E. Schreiber, P. Jiménez-Lozano, J.M. Poblet, C. de Graaf, R. Neumann, Inorg. Chem., 53 (2014) 1779-1787.

[69] P. Jiménez-Lozano, J.J. Carbó, A. Chaumont, J.M. Poblet, A. Rodríguez-Fortea, G. Wipff, Inorg. Chem., 53 (2014) 778-786.
[70] P. Jiménez-Lozano, I.D. Ivanchikova, O.A. Kholdeeva, J.M. Poblet, J.J. Carbó, Chem. Commun., 48 (2012) 9266-9268.

[71] X. López, I.A. Weinstock, C. Bo, J.P. Sarasa, J.M. Poblet, Inorg. Chem., 45 (2006) 6467-6473.

[72] X. López, J.J. Carbo, C. Bo, J.M. Poblet, Chem. Soc. Rev., 41 (2012) 7537-7571.

[73] Y. Surendranath, M.W. Kanan, D.G. Nocera, J. Am. Chem. Soc., 132 (2010) 16501-16509.

[74] M.J. Frisch, G.W. Trucks, H.B. Schlegel, G.E. Scuseria, M.A. Robb, J.R. Cheeseman, G. Scalmani, V. Barone, B. Mennucci, G.A. Petersson, H. Nakatsuji, M. Caricato, X. Li, H.P. Hratchian, A.F. Izmaylov, J. Bloino, G. Zheng, J.L. Sonnenberg, M. Hada, M. Ehara, K. Toyota, R. Fukuda, J. Hasegawa, M. Ishida, T. Nakajima, Y. Honda, O. Kitao, H. Nakai, T. Vreven, J.A. Montgomery, J.E. Peralta, F. Ogliaro, M. Bearpark, J.J. Heyd, E. Brothers, K.N. Kudin, V.N. Staroverov, R. Kobayashi, J. Normand, K. Raghavachari, A. Rendell, J.C. Burant, S.S. Iyengar, J. Tomasi, M. Cossi, N. Rega, J.M. Millam, M. Klene, J.E. Knox, J.B. Cross, V. Bakken, C. Adamo, J. Jaramillo, R. Gomperts, R.E. Stratmann, O. Yazyev, A.J. Austin, R. Cammi, C. Pomelli, J.W. Ochterski, R.L. Martin, K. Morokuma, V.G. Zakrzewski, G.A. Voth, P. Salvador, J.J. Dannenberg, S. Dapprich, A.D. Daniels, Farkas, J.B. Foresman, J.V. Ortiz, J. Cioslowski, D.J. Fox, Gaussian 09, Revision C.01, in, Wallingford CT, 2010.

[75] C. Lee, C. Yang, R.G. Parr, Phys. Rev. B, 38 (1988) 785-789.

[76] A.D. Becke, J. Chem. Phys., 98 (1993) 5648-5652.

[77] P.J. Stephens, F.J. Devlin, C.F. Chabalowski, M.J. Frisch, J. Phys. Chem., 98 (1994) 11623-11627.

[78] K. Kwapien, S. Piccinin, S. Fabris, J. Phys. Chem. Lett., 4 (2013) 4223-4230.

[79] K. Nishiki, N. Umehara, Y. Kadota, X. López, J.M. Poblet, C.A. Mezui, A.-L. Teillout, I.M. Mbomekalle, P.d. Oliveira, M. 
Miyamoto, T. Sanoa, M. Sadakane, Dalton Trans., 45 (2016)

$3175-3726$.

[80] P.A. Aparicio, J.M. Poblet, X. López, Eur. J. Inorg. Chem., (2013) 1910-1916.

[81] P. Jiménez-Lozano, I.Y. Skobelev, O.A. Kholdeeva, J.M. Poblet, J.J. Carbó, Inorg. Chem., (2016) 6080-6084.

[82] C. Ci, J.J. Carbó, R. Neumann, C.d. Graaf, J.M. Poblet, ACS Catal., (2016) 6422-6428.

[83] P.J. Hay, W.R. Wadt, J. Chem. Phys., 82 (1985) 270-283.

[84] M.M. Francl, W.J. Pietro, W.J. Hehre, J.S. Binkley, M.S. Gordon, D.J. Defrees, J.A. Pople, J. Chem. Phys., 77 (1982) 36543665.

[85] W.J. Hehre, R. Ditchfield, J.A. Pople, J. Chem. Phys., 56 (1972) 2257-2261.

[86] P.C. Hariharan, J.A. Pople, Theor. Chim. Acta, 25 (1973) $213-222$.

[87] E. Cances, B. Mennucci, J. Tomasi, J. Chem. Phys., 107 (1997) 3032-3041.

[88] M. Álvarez-Moreno, C. de Graaf, N. Lopez, F. Maseras, J.M. Poblet, C. Bo, J. Chem. Inf. Model., 55 (2015) 95-103.

[89] J. Li, C.L. Fisher, J.L. Chen, D. Bashford, L. Noodleman, Inorg. Chem., 35 (1996) 4694-4702.

[90] J.R. Buchwald, S. Kal, P.H. Dinolfo, J. Phys. Chem. C, 118 (2014) 25869-25877. 